\title{
7,8-Dihydroxyflavone exhibits anti-inflammatory properties by downregulating the NF-кB and MAPK signaling pathways in lipopolysaccharide-treated RAW264.7 cells
}

\author{
HYE YOUNG PARK ${ }^{1,2}$, GI-YOUNG KIM ${ }^{3}$, JIN WON HYUN ${ }^{4}$, HYE JIN HWANG ${ }^{5,7}$, \\ NAM DEUK KIM ${ }^{2}$, BYUNG-WOO KIM ${ }^{6-8}$ and YUNG HYUN CHOI ${ }^{1,7,8}$
}

\author{
${ }^{1}$ Department of Biochemistry, Dongeui University College of Oriental Medicine, Busan; ${ }^{2}$ Department of Pharmacy, \\ Pusan National University, Busan; ${ }^{3}$ Laboratory of Immunobiology, Department of Marine Life Sciences; \\ ${ }^{4}$ School of Medicine and Applied Radiological Science Research Institute, Jeju National University, Jeju; \\ ${ }^{5}$ Department of Food and Nutrition, College of Human Ecology, Busan; ${ }^{6}$ Department of Life Science and Biotechnology, \\ College of Natural Science, Busan; ${ }^{7}$ Department of Biomaterial Control (BK21 Program), Graduate School; \\ ${ }^{8}$ Blue-Bio Industry Regional Innovation Center, Dongeui University, Busan, Republic of Korea
}

Received December 27, 2011; Accepted February 15, 2012

DOI: 10.3892/ijmm.2012.935

\begin{abstract}
Dihydroxyflavone (7,8-DHF), a member of the flavonoid family, has received considerable attention as a selective tyrosine kinase receptor B agonist. Several studies have indicated that 7,8-DHF has neurotrophic and antioxidant activities. However, little is known about the cellular and molecular mechanisms underlying the anti-inflammatory activity of 7,8-DHF. Therefore, we investigated whether 7,8-DHF affects the expression of inflammatory mediators in lipopolysaccharide (LPS)-stimulated RAW264.7 cells. Our results indicated that 7,8-DHF significantly attenuated secretion of LPS-induced inflammatory mediators nitric oxide (NO), prostaglandin $\mathrm{E}_{2}\left(\mathrm{PGE}_{2}\right)$ and interleukin-1 $\beta$ (IL-1 $\beta$ ) in RAW264.7 cells. Additionally, LPS-induced expression of inducible NO synthase (iNOS), cyclooxygenase (COX)-2 and IL- $1 \beta$ was decreased by pre-treatment with 7,8-DHF. Our results also showed that 7,8-DHF reduces LPS-induced nuclear factor- $\kappa \mathrm{B}(\mathrm{NF}-\kappa \mathrm{B})$ activity via the suppression of the nuclear translocation of NF- $\kappa \mathrm{B}$ p65 and the degradation of inhibitor $\kappa \mathrm{B}(1 \kappa \mathrm{B})$. In addition, 7,8-DHF inhibited the phosphorylation of mitogen-activated protein kinases (MAPKs) such as extracellular-signal-related kinase (ERK), p38, and c-Jun N-terminal kinase (JNK). These results suggest that the anti-inflammatory property of 7,8-DHF is related to the downregulation of iNOS, COX-2 and IL-1 $\beta$, due to NF- $\mathrm{KB}$ inhibition as well as to the negative regulation of MAPK activation in
\end{abstract}

Correspondence to: Dr Yung Hyun Choi, Department of Biochemistry, Dongeui University College of Oriental Medicine, Busan 614-052, Republic of Korea

E-mail: choiyh@deu.ac.kr

Key words: 7,8-dihydroxyflavone, anti-inflammation, NF-кB, MAPKs
RAW264.7 cells. Thus, 7,8-DHF may be a novel therapeutic agent for the prevention of various inflammatory diseases.

\section{Introduction}

Inflammation, a physiological response to infection or injury, plays a critical role in health and disease. Inflammation is a delicate mechanism composed of cellular immunity and biochemical mediators, mediated by activated inflammatory and immune cells including macrophages. In response to infection or injury, macrophages readily become activated and secrete neurotoxic and pro-inflammatory mediators, including nitric oxide $(\mathrm{NO})$, prostaglandin $\mathrm{E}_{2}\left(\mathrm{PGE}_{2}\right)$, reactive oxygen species (ROS), and pro-inflammatory cytokines, such as interleukin-1 $\beta$ (IL-1 $\beta$ ), IL- 6 and tumor necrosis factor- $\alpha$ (TNF- $\alpha$ ) (1-3). Excessive NO production during inflammation is linked to tissue damage and organ dysfunction due to the massive expression of inducible NO synthase (iNOS) expression $(4,5)$. Cyclooxygenases (COXs), in the prostaglandin biosynthesis pathway, are key enzymes that catalyze the conversion of arachidonic acid to $\mathrm{PGE}_{2}$. It is generally accepted that $\mathrm{PGE}_{2}$ is produced by COX-2 at sites of inflammation, and that COX-1, another constitutive isoform, is relevant in the production of prostaglandins that regulate normal cellular processes (6). NO also acts as a modulator of COX-2 activity and directly affects its enzymatic activity (7). In addition, IL-1 $\beta$ is a potential inflammatory cytokine involved in the induction of innate immune responses by macrophages and in stimulating secretion of other inflammatory cytokines $(8,9)$. Thus, the regulation of macrophage activation and downregulation of pro-inflammatory mediators, including $\mathrm{NO}, \mathrm{PGE}_{2}$ and IL-1 $\beta$ in macrophages, may be safe and effective interventions for inflammatory diseases

In response to macrophage activation by an endotoxin such as lipopolysaccharide (LPS), the Toll-like receptor 4 (TLR4)-myeloid differentiation factor (MyD88) pathway 
induces rapid phosphorylation of mitogen-activated protein kinases (MAPKs) and inhibitor $\kappa \mathrm{B}(\mathrm{I} \kappa \mathrm{B})$ kinase $(\mathrm{IKK})$ through activation of transforming growth factor- $\beta$-activated kinase 1 (TAK1), eventually contributing to the activation of nuclear factor $\kappa \mathrm{B}(\mathrm{NF}-\kappa \mathrm{B})$ and activator protein-1 (AP-1) $(10,11)$. The transcription factor $N F-\kappa B$ is activated through the phosphorylation and subsequent degradation of $\mathrm{I} \kappa \mathrm{B}$ by IKK, and plays a central role in the onset of inflammation by increasing the level of inflammatory mediators $(10,12,13)$. The gene expression of these inflammatory mediators is also regulated by AP-1, another transcription factor that is crucial for inflammation. AP-1 is mainly activated through MAPKs such as extracellular-signal-related kinase (ERK), p38 and c-Jun N-terminal kinase (JNK) (14-16). Therefore, many putative anti-inflammatory therapies are based on the blocking of $\mathrm{NF}-\kappa \mathrm{B}$ and MAPK activity.

Flavonoids are a diverse group of natural plant products synthesized from phenylpropanoid and acetate-derived precursors that are present in high concentrations in fruits and vegetables $(17,18)$. They are becoming an important source of novel agents with pharmaceutical potential and have attracted a great deal of attention for their role in the prevention of chronic diseases (19-21). Flavonoids display a remarkable spectrum of biological properties, including anti-allergic, antiinflammatory, antioxidant, and anticancer effects, as well as immunomodulation and modulation of enzymatic activities (22-26). Among them, 7,8-dihydroxyflavone (7,8-DHF) is a recently identified tyrosine kinase receptor $\mathrm{B}(\operatorname{TrkB})$ agonist that can cross the blood-brain barrier $(18,27,28)$. Recently, 7,8-DHF has been reported to have neurotrophic activities in various neurological diseases, such as stroke and Parkinson's disease (27). Although several studies on the antioxidant effects of 7,8-DHF have been carried out $(18,29,30)$, the molecular mechanisms underlying its anti-inflammatory effects have yet to be reported.

In this study, we investigated the inhibitory effects of 7,8-DHF and the manner in which it induces anti-inflammatory mechanisms in lipopolysaccharide (LPS)-stimulated inflammatory mediator production in RAW264.7 cells. This is the first study reporting that 7,8-DHF significantly attenuates the levels of $\mathrm{NO}, \mathrm{PGE}_{2}$ and IL-1 $\beta$ in LPS-stimulated murine macrophage RAW264.7 cells via suppression of the $N F-\kappa B$ and MAPK signaling pathways.

\section{Materials and methods}

Cell culture. RAW264.7 murine macrophage cells were kindly provided by Professor Il Whan Choi of Inje University (Busan, Korea) and cultured at $37^{\circ} \mathrm{C}$ in $5 \% \mathrm{CO}_{2}$ in Dulbecco's modified Eagle's medium (DMEM, Gibco BRL, Gaithersburg, MD) supplemented with $10 \%$ fetal bovine serum (FBS), $100 \mathrm{U} /$ $\mathrm{ml}$ penicillin and $100 \mu \mathrm{g} / \mathrm{ml}$ streptomycin. The 7,8-DHF was obtained from Professor Jin Won Hyun of Jeju National University (Jeju, Korea) and dissolved in dimethyl sulfoxide (DMSO); dilutions were made in DMEM. The final concentration of DMSO in the medium was $<0.0005 \%$ ( $\mathrm{vol} / \mathrm{vol}$ ), which had no impact on cell growth. In all experiments, cells were pre-treated with the indicated concentrations of 7,8-DHF for $1 \mathrm{~h}$ prior to the addition of LPS (Sigma-Aldrich Chemical Co., St. Louis, MO).
Cell viability assay. Cell viability was measured based on the formation of blue formazan metabolized from colorless 3-(4,5-dimethylthiazol-2-yl)-2,5-diphenyltetrazolium bromide (MTT, Sigma-Aldrich) by mitochondrial dehydrogenases, which are active only in viable cells. RAW264.7 cells were plated into 24 -well plates at a density of $2 \times 10^{5}$ cells/well for $24 \mathrm{~h}$, and then washed. The cells incubated with various concentrations of $7,8-\mathrm{DHF}$ were treated with or without $0.5 \mu \mathrm{g} / \mathrm{ml}$ LPS for $24 \mathrm{~h}$, and then incubated in $0.5 \mathrm{mg} / \mathrm{ml}$ MTT solution. Three hours later, the supernatant was removed and formation of formazan was measured at $540 \mathrm{~nm}$ using a microplate reader (31).

Measurement of NO production. Concentrations of NO in culture supernatants were determined as nitrite, a major stable product of NO, using the Griess reagent (Sigma-Aldrich). After cells $\left(5 \times 10^{5}\right.$ cells $\left./ \mathrm{ml}\right)$ were stimulated in 24-well plates for $24 \mathrm{~h}, 100 \mu \mathrm{l}$ of each cultured medium was mixed with the same volume of the Griess reagent [ $1 \%$ sulfanilamide $/ 0.1 \%$ $\mathrm{N}$-(1-naphthyl)-ethylenediamine dihydrochloride/2.5\% $\mathrm{H}_{3} \mathrm{PO}_{4}$ ). Nitrite levels were determined using an ELISA plate reader at $540 \mathrm{~nm}$, and nitrite concentrations were calculated by reference to a standard curve generated by known concentrations of sodium nitrite (32).

Measurement of $P G E_{2}$ production. RAW264.7 cells were incubated with 7,8-DHF in either the presence or absence of LPS $(0.5 \mu \mathrm{g} / \mathrm{ml})$ for $24 \mathrm{~h}$. Following the manufacturer's instructions, a volume of $100 \mu \mathrm{l}$ of culture-medium supernatant was collected to determine $\mathrm{PGE}_{2}$ concentration by ELISA (Cayman, MI) (33).

Reverse transcriptase-polymerase chain reaction. Total RNA was isolated using TRIzol reagent (Invitrogen, CA). Total RNA $(1.0 \mu \mathrm{g})$ obtained from cells was primed with random hexamers to synthesize complementary DNA using M-MLV reverse transcriptase (Promega, Madison, WI), according to the manufacturer's instructions. Polymerase chain reaction (PCR) was performed for amplification of the IL-1 $\beta$ gene from the cDNA, and glyceraldehyde-3-phosphate dehydrogenase (GAPDH) was used as an internal control. Conditions for the PCR reactions were $1 \times\left(94^{\circ} \mathrm{C}\right.$ for $\left.3 \mathrm{~min}\right) ; 35 \times\left(94^{\circ} \mathrm{C}\right.$ for $45 \mathrm{sec}$; $58^{\circ} \mathrm{C}$ for $45 \mathrm{sec}$; and $72^{\circ} \mathrm{C}$ for $\left.1 \mathrm{~min}\right)$; and $1 \times\left(72^{\circ} \mathrm{C}\right.$ for $\left.10 \mathrm{~min}\right)$. Amplification products obtained by PCR were electrophoretically separated on $1 \%$ agarose gel and visualized by ethidium bromide $(\mathrm{EtBr})$ staining.

Protein extraction and western blot analysis. For western blot analysis, cells were harvested and washed twice in phosphate-buffered saline (PBS) at $4^{\circ} \mathrm{C}$. Total cells lysates were lysed in lysis buffer [40 mM Tris ( $\mathrm{pH} 8.0), 120 \mathrm{mM}$, $\mathrm{NaCl}, 0.5 \% \mathrm{NP}-40,0.1 \mathrm{mM}$ sodium orthovanadate, $2 \mu \mathrm{g} / \mathrm{ml}$ aprotinin, $2 \mu \mathrm{g} / \mathrm{ml}$ leupeptin, and $100 \mu \mathrm{g} / \mathrm{ml}$ phenymethylsulfonyl fluoride]. The supernatants were collected and protein concentrations were then measured with protein assay reagents (Pierce Biotechnology, Rockford, IL). Equal amounts of protein extracts were denatured by boiling at $95^{\circ} \mathrm{C}$ for $5 \mathrm{~min}$ in sample buffer $(0.5 \mathrm{M}$ Tris- $\mathrm{HCl}$, pH $6.8,4 \%$ SDS, $20 \%$ glycerol, $0.1 \%$ bromophenol blue, $10 \% \beta$-mercaptoethanol) in a ratio of $1: 1$, subjected to 
A

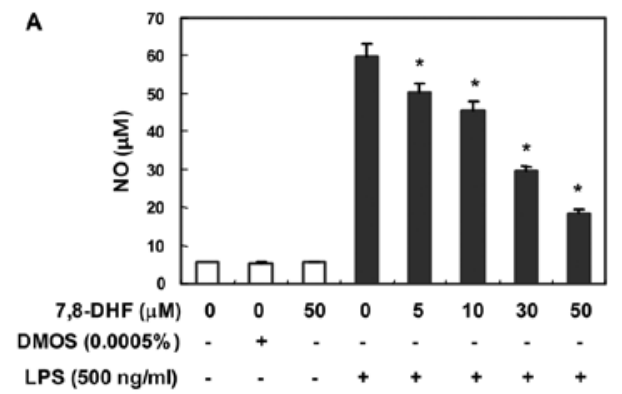

B

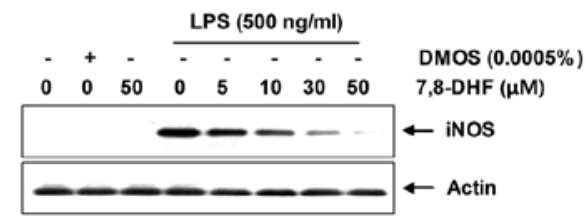

Figure 1. Inhibition of NO production and iNOS expression by 7,8-DHF in LPS-stimulated RAW264.7 cells. RAW264.7 cells were pre-treated with various concentrations of 7,8-DHF for $1 \mathrm{~h}$ prior to incubation with LPS $(0.5 \mu \mathrm{g} / \mathrm{ml})$ for $24 \mathrm{~h}$. (A) Nitrite content was measured using the Griess reaction. Each value indicates the mean $\pm \mathrm{SD}$ and is representative of results obtained from three independent experiments. " $\mathrm{p}<0.05$ indicates a significant difference from the value obtained for cells treated with LPS in the absence of 7,8-DHF. (B) After $24 \mathrm{~h}$ treatment, the cells were lysed and the cellular proteins $(50 \mu \mathrm{g})$ were separated by electrophoresis on SDS-polyacrylamide gel and transferred to nitrocellulose membranes. Membranes were probed with ant-iNOS antibody and the proteins were visualized using an ECL detection system. Actin was used as an internal control.

8-10\% sodium dodecyl sulfate (SDS)-polyacrylamide gels, and transferred to polyvinylidene difluoride membranes (Schleicher \& Schuell, Keene, NH) by electroblotting. The membranes were blocked with $5 \%$ non-fat dry milk in PBS with Tween-20 buffer (PBS-T) (20 mM Tris, $100 \mathrm{mM} \mathrm{NaCl}$, $\mathrm{pH} 7.5$, and $0.1 \%$ Tween-20) for $1 \mathrm{~h}$ at room temperature. Membranes were then incubated overnight at $4^{\circ} \mathrm{C}$ with the primary antibodies, probed with enzyme-linked secondary antibodies, and visualized using an enhanced chemiluminescence (ECL) kit (Amersham, Arlington Heights, IL), according to the manufacturer's instructions. In a parallel experiment, nuclear proteins were prepared using the NE-PER nuclear extraction reagent (Pierce Biotechnology), according to the manufacturer's protocol.

Enzyme immunosolvent assay (ELISA). The levels of IL-1 $\beta$ were measured by the ELISA kit (R\&D Systems, Minneapolis, $\mathrm{MN}$ ), according to the manufacturer's instructions. Briefly, RAW264.7 cells $\left(5 \times 10^{5}\right.$ cells $\left./ \mathrm{ml}\right)$ were plated in 24 -well plates and pre-treated with the indicated concentrations of 7,8-DHF for $1 \mathrm{~h}$ before treatment of $0.5 \mu \mathrm{g} / \mathrm{ml} \mathrm{LPS}$ for $24 \mathrm{~h}$. One hundred microliters of culture-medium supernatants were collected for determination of IL-1 $\beta$ concentration by ELISA (34).

Statistical analyses. Data values represent the means \pm SD Statistical significance was determined using an analysis of variance, followed by the Student's t-test. A value of $p<0.05$ was considered to indicate a statistically significant difference.

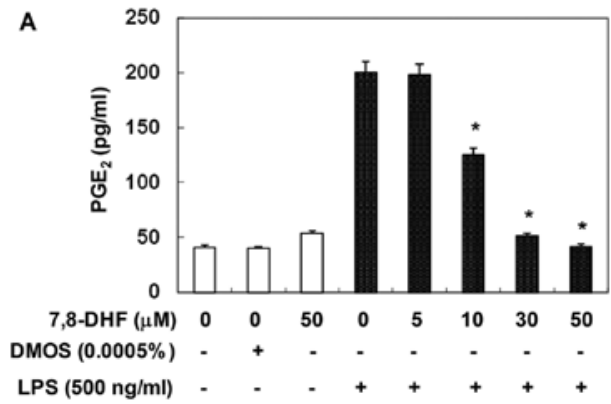

B

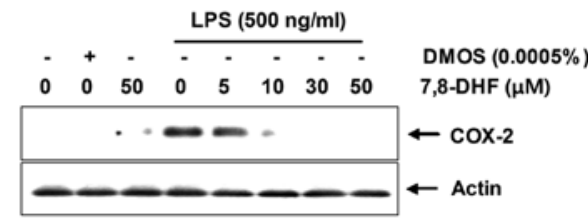

Figure 2. Inhibition of $\mathrm{PGE}_{2}$ production and COX-2 expression by 7,8-DHF in LPS-stimulated RAW264.7 cells. RAW264.7 cells were pre-treated with various concentrations of 7,8-DHF for $1 \mathrm{~h}$ prior to incubation with LPS $(0.5 \mu \mathrm{g} / \mathrm{ml})$ for $24 \mathrm{~h}$. (A) A commercially available ELISA kit was used for measurement of $\mathrm{PGE}_{2}$ in the resulting supernatants. Each value indicates the mean \pm SD and is representative of results obtained from three independent experiments. ${ }^{*} \mathrm{p}<0.05$ indicates a significant difference from the value obtained for cells treated with LPS in the absence of 7,8-DHF. (B) Following $24 \mathrm{~h}$ treatment, the cells were lysed and the cellular proteins $(50 \mu \mathrm{g})$ were separated by electrophoresis on SDS-polyacrylamide gel and transferred to nitrocellulose membranes. Membranes were probed with anti-COX-2 antibody and the proteins were visualized using an ECL detection system. Actin was used as an internal control.

\section{Results}

7,8-DHF attenuates NO production via suppression of iNOS expression. To investigate the effects of 7,8-DHF on NO production, cell culture supernatants were collected, and the levels of nitrite were measured with the Griess reagent. Stimulation with LPS alone resulted in an approximate 10-fold increase in NO production compared with the untreated control; however, 7,8-DHF resulted in a concentration-dependent decrease in NO production. In particular, pre-treatment for $1 \mathrm{~h}$ with $30 \mu \mathrm{M}$ and $50 \mu \mathrm{M}$ 7,8-DHF greatly decreased NO production by more than 60 and $46 \%$, respectively, compared with LPS alone (Fig. 1A). Next, we evaluated whether 7,8-DHF treatment decreases protein expression of iNOS in LPS-stimulated RAW264.7 cells using western blot analysis. Stimulation with LPS alone significantly induced expression of iNOS protein; however, 7,8-DHF markedly inhibited expression of the LPS-induced iNOS protein (Fig. 1B). The data suggest that 7,8-DHF inhibits LPS-induced NO production via suppression of iNOS expression.

7,8-DHF decreases LPS-induced $P G E_{2}$ production via suppression of COX-2 expression. As it is well known that $\mathrm{PGE}_{2}$ is involved in the production of pro-inflammatory agents, we examined the effects of 7,8-DHF on $\mathrm{PGE}_{2}$ secretion in LPS-stimulated RAW264.7 cells. As shown in Fig. 2A, stimulation with LPS alone significantly increased secretion of $\mathrm{PGE}_{2}>4.5$-fold compared with the control, 
A

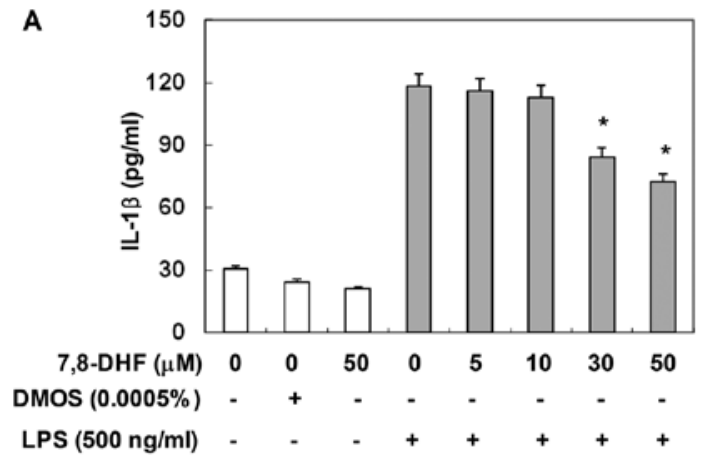

B

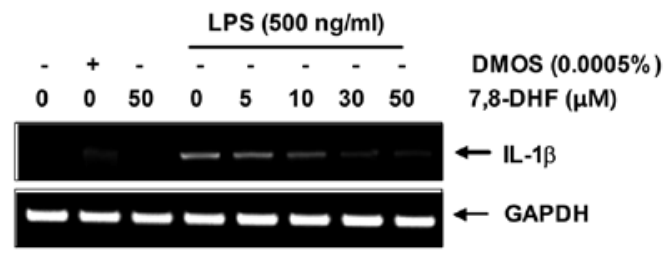

Figure 3. Effects of 7,8-DHF on LPS-stimulated IL-1 $\beta$ production and expression in RAW264.7 cells. (A) RAW264.7 cells were pre-treated with 7,8 -DHF for $1 \mathrm{~h}$ prior to LPS treatment $(0.5 \mu \mathrm{g} / \mathrm{ml})$. After incubation for $24 \mathrm{~h}$, levels of IL-1 $\beta$ present in the supernatants were measured. Each value indicates the mean $\pm \mathrm{SD}$ and is representative of results obtained from three independent experiments. "p $<0.05$ indicates a significant difference from the value obtained for cells treated with LPS in the absence of 7,8-DHF. (B) Cells were pre-treated with 7,8-DHF for $1 \mathrm{~h}$ prior to LPS treatment $(0.5 \mu \mathrm{g} / \mathrm{ml})$, and total RNA was isolated $6 \mathrm{~h}$ after LPS treatment. RT-PCR was performed to determine the levels of IL- $1 \beta$ mRNA. The experiment was repeated three times and similar results were obtained.

while 7,8-DHF reversed the increased $\mathrm{PGE}_{2}$ production in a concentration-dependent manner. Pre-treatment with $50 \mu \mathrm{M}$ 7,8-DHF decreased LPS-induced $\mathrm{PGE}_{2}$ production to approximately control levels. Consistent with these data, treatment of cells with LPS alone significantly increased expression of the COX-2 protein (Fig. 2B), which is the ratelimiting enzyme of $\mathrm{PGE}_{2}$ production. However, 7,8-DHF concentration-dependently inhibited this increase in LPS-stimulated RAW264.7 cells. Taken together, these data indicate that 7,8-DHF significantly suppresses the release of $\mathrm{PGE}_{2}$ in LPS-stimulated RAW264.7 cells via suppression of the COX-2 expression.

7,8-DHF suppresses IL-1 $\beta$ secretion via suppression of the $I L-1 \beta$ gene expression. IL-1 $\beta$ is one of the major pro-inflammatory cytokines induced by LPS. Therefore, we assessed whether 7,8-DHF modulates secretion of IL-1 $\beta$ in LPS-stimulated RAW264.7 cells. As indicated in Fig. 3A, IL-1 $\beta$ secretion was significantly increased by LPS stimulation alone at $24 \mathrm{~h}$; however, pre-treatment with 7,8-DHF resulted in a decrease in the release of IL-1 $\beta$ in a concentration-dependent manner (Fig. 3A). To investigate the effect of 7,8-DHF pre-treatment on the expression of IL-1 $\beta$, reverse transcription-PCR analysis was performed. Consistent with the attenuation of IL-1 $\beta$ secretion, 7,8-DHF reduced the expression of IL-1 $\beta$ mRNA in LPS-stimulated RAW264.7 cells compared with LPS alone (Fig. 3B). These results suggest that 7,8-DHF suppresses LPS-stimulated IL-1 $\beta$ release through attenuation of the IL-1 $\beta$ mRNA expression.
A

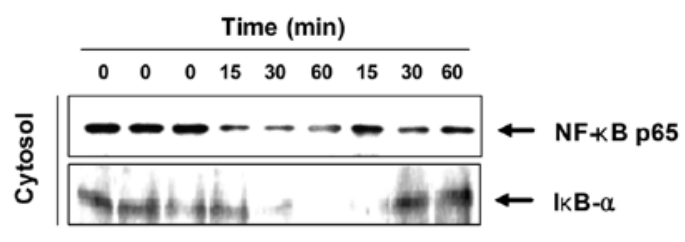

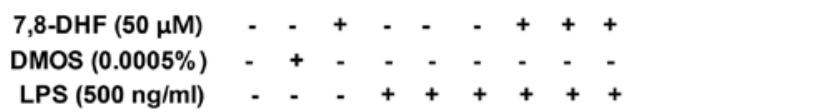

B

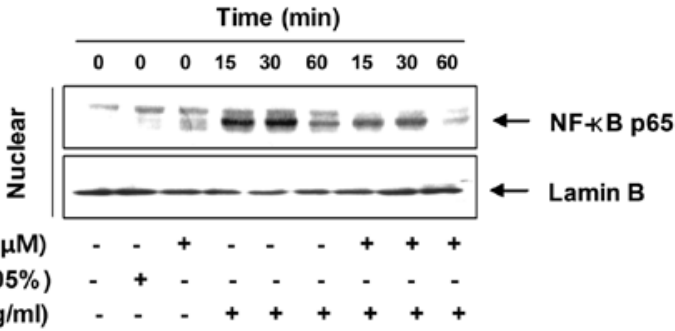

Figure 4. Effects of 7,8-DHF on LPS-induced NF- $\kappa$ B translocation and ІкB degradation in RAW264.7 cells. Cells were treated with 7,8-DHF for $1 \mathrm{~h}$ prior to LPS treatment $(0.5 \mu \mathrm{g} / \mathrm{ml})$ for the indicated times. (A) Cytosolic and (B) nuclear proteins were subjected to $10 \%$ SDS-polyacrylamide gels fol-

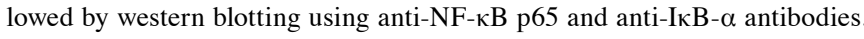
Results are representative of those obtained from two independent experiments. Lamin B was used as an internal control for nuclear fractions.

7,8-DHF blocks LPS-induced NF- $\kappa B$ activation. Since NF-кB is a critical transcriptional factor that regulates LPS-induced expression of genes for pro-inflammatory mediators, including iNOS, COX-2 and IL-1 $\beta$, we investigated whether 7,8-DHF modulates the activation of NF- $\mathrm{\kappa B}$ in RAW264.7 cells in response to LPS. To verify the regulation of NF- $\mathrm{KB}$ activity, we examined the effect of 7,8-DHF on LPS-induced nuclear translocation of the NF- $\mathrm{\kappa B}$ p65 subunit and IкB- $\alpha$ degradation by western blot analysis. Our immunoblotting data indicated that stimulation of cells with LPS induced the degradation of Iк $\mathrm{B} \alpha$, and the translocation of the NF- $\mathrm{B}$ p 65 subunit from the cytosol to the nucleus (Fig. 4A). However, LPS-induced IкB degradation was inhibited after $30 \mathrm{~min}$ of exposure to 7,8-DHF. Additionally, 7,8-DHF inhibited nuclear translocation of the NF-kB p65 protein (Fig. 4B). Taken together, our findings demonstrate that 7,8-DHF inhibits the NF- $\mathrm{KB}$ signaling pathway via suppression of the nuclear translocation

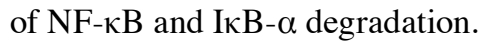

7,8-DHF reduces LPS-induced phosphorylation of MAPKs. To further investigate other intracellular mechanisms responsible for the inhibitory effect of 7,8-DHF on inflammatory mediators, we examined the effect of 7,8-DHF on MAPK signaling pathways. As shown in Fig. 5, stimulation of RAW264.7 cells with LPS led to rapid activation of p38, ERK and JNK with the peak levels of each phospho-MAPK occurring 15 to $60 \mathrm{~min}$ after the addition of LPS. However, 7,8-DHF pre-treatment significantly inhibited phosphorylation of these MAPKs in LPS-stimulated RAW264.7 cells. These results suggest that the activation of MAPKs may be involved in the inhibitory effect of 7,8-DHF on LPS-induced pro-inflammatory mediators in RAW264.7 cells. 


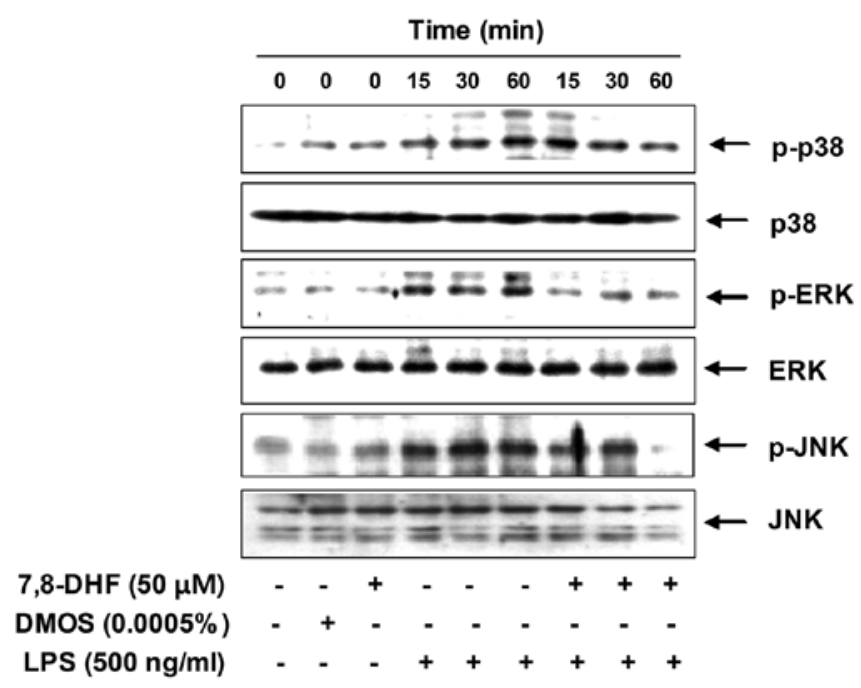

Figure 5. Effects of 7,8-DHF on MAPK activation induced by LPS in RAW264.7 cells. Cells were treated with the indicated concentrations of 7,8DHF for $1 \mathrm{~h}$ prior to LPS $(0.5 \mu \mathrm{g} / \mathrm{ml})$ treatment for the indicated times. Total protein was subjected to $10 \%$ SDS-polyacrylamide gels, followed by western blotting using the indicated antibodies. Proteins were visualized using an ECL detection system.

7,8-DHF does not affect cell viability. To assess whether or not the anti-inflammatory effects of 7,8-DHF in RAW264.7 cells were due to its cytotoxic effects, an MTT assay was performed $24 \mathrm{~h}$ after treatment with the indicated concentrations of 7,8-DHF in the presence or absence of LPS. Results from the MTT assay showed that the concentrations $(5-50 \mu \mathrm{M})$ used for inhibition of NO, $\mathrm{PGE}_{2}$ and IL-1 $\beta$ production did not affect cell viability (Fig. 6). In addition, LPS $(0.5 \mu \mathrm{g} / \mathrm{ml})$ alone was not cytotoxic and vehicle control $(0.0005 \%$ DMSO) also had no impact on cell viability. The results confirmed that inhibition of $\mathrm{NO}, \mathrm{PGE}_{2}$ and IL-1 $\beta$ production in LPS-stimulated RAW264.7 cells was not due to a cytotoxic action of 7,8-DHF.

\section{Discussion}

In the present study, we demonstrated that 7,8-DHF in LPS-activated RAW264.7 cells inhibits LPS-induced production of key pro-inflammatory mediators, such as $\mathrm{NO}, \mathrm{PGE}_{2}$ and IL-1 $\beta$. These effects were accompanied by downregulation of the NF- $\kappa B$ activity, and inactivation of the MAPK signaling pathway without cytotoxicity.

Inflammation is the first response of the immune system to infection or irritation. Pro-inflammatory mediators such as iNOS, COX-2 and IL-1 $\beta$ play a crucial role in immune responses by increasing the levels of $\mathrm{NO}, \mathrm{PGE}_{2}$, and IL-1 $\beta$, which result in many of the damaging effects observed in inflammation-related diseases (1-3). Although the production of pro-inflammatory mediators is important to promote anti-bacterial, anti-viral, and anticancer response, excessive production is involved in the initiation and process of severe inflammation $(16,35,36)$. Thus, inhibitors of these inflammatory mediators have been considered as candidates for the development of drugs and functional foods to attenuate inflammatory diseases. In this study, as a component of our

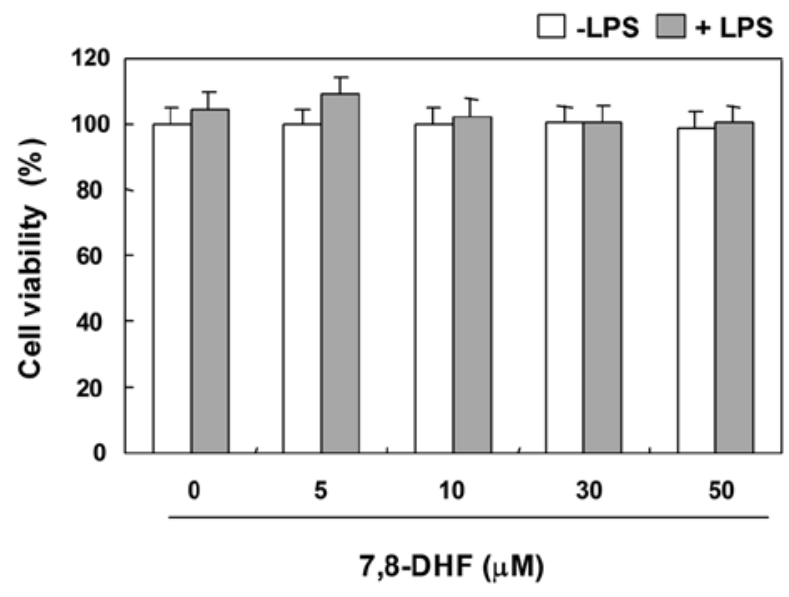

Figure 6. Effects of 7,8-DHF and LPS on the cell viability of RAW264.7 cells. Cells were treated with the indicated concentrations of 7,8-DHF $1 \mathrm{~h}$ prior to LPS $(0.5 \mu \mathrm{g} / \mathrm{ml})$ treatment for $24 \mathrm{~h}$. Cell viability was assessed by MTT reduction assays and the results are expressed as the percentage of surviving cells over control cells (no addition of 7,8-DHF). Values are the means \pm SD of three independent experiments.

ongoing screening for new biologically active compounds from natural compounds, we tested the effects of 7,8-DHF, a member of the flavonoid family, on the production of inflammatory mediators in LPS-stimulated RAW264.7 macrophages. We found that 7,8-DHF significantly decreased secretion levels of LPS-induced NO, $\mathrm{PGE}_{2}$ and IL-1 $\beta$, which was associated with the suppression of iNOS, COX-2 and IL- $1 \beta$ expression, respectively.

The transcription factor NF- $\mathrm{KB}$ is a primary regulator of genes that tightly regulates the expression of many genes involved in severe inflammatory diseases $(10,11)$. The blockade of NF- $\kappa \mathrm{B}$ transcriptional activity is also known to suppress expression of pro-inflammatory mediators including iNOS, COX-2, and IL-1ß (37-39). Therefore, downregulation of NF- $\kappa$ B activity is a useful strategy to regulate inflammatory diseases. Previous reports have indicated that stimulation with LPS induces IкB phosphorylation and proteosomal degradation in cytosol, which

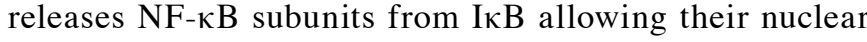
translocation and subsequent binding to their specific promoter regions. This leads to the activation of several signal transduction pathways in macrophages that trigger the secretion of inflammatory mediators $(10,12,13)$. Thus, we evaluated the effect of 7,8-DHF on LPS-induced NF- $\mathrm{KB}$ activation to confirm whether the inhibitory effects of 7,8 -DHF on the production of $\mathrm{NO}, \mathrm{PGE}_{2}$ and IL- $1 \beta$ were regulated by the NF- $\kappa \mathrm{B}$ signaling pathway. We found that the translocation of NF- $\kappa \mathrm{B}$ factor p65, which is normally translocated from the cytoplasm to the nucleus after exposure to LPS, was strongly inhibited by 7,8-DHF through blockage of LPS-induced IкB- $\alpha$ degradation. This result suggests that the inhibitory effects of 7,8-DHF on the production of inflammatory mediators are at least partially mediated by the suppression of the NF- $\kappa \mathrm{B}$ signaling pathway.

Involvement of various intracellular signaling pathways, such as MAPKs, in inflammatory mediator induction has been reported (14-16). LPS is also known to activate a series 
of MAPKs, such as ERK, p38 and JNK after engagement of cluster of differentiation 14/Toll-like receptor 4 (CD14/ TLR) receptors on the cell surface in macrophages, which play important roles in LPS-induced cellular responses $(40,41)$. Therefore, subsequent experiments were performed to determine the effects of 7,8-DHF on the LPS-induced phosphorylation of MAPKs in RAW264.7 cells. As shown in our results, LPS induced rapid phosphorylation of ERK, JNK and p38 in RAW264.7 cells. However, 7,8-DHF markedly inhibited LPS-induced phosphorylation of these kinases. These results indicate that the effects of 7,8 -DHF on the production of inflammatory mediators could occur through the blocking of the MAPK signaling pathway.

In conclusion, the results presented in this study, demonstrate that 7,8-DHF inhibits LPS-induced NO, $\mathrm{PGE}_{2}$ and IL-1 $\beta$ production by suppressing iNOS, COX-2 and IL-1 $\beta$ expression in RAW264.7 macrophage cells. The inhibitory action of 7,8-DHF was mediated by the prevention of $\mathrm{NF}-\kappa \mathrm{B}$ activation and by the inhibition of I $\kappa \mathrm{B}$-degradation, which is accompanied by the blocking of the MAPK pathways. As a result of the findings presented in this report, we suggest that 7,8 -DHF may provide an effective treatment for numerous inflammatory diseases.

\section{Acknowledgements}

This study was supported by the R\&D program of MKE/KEIT (10040391, Development of Functional Food Materials and Device for Prevention of Aging-associated Muscle Function Decrease).

\section{References}

1. Abramson SB, Attur M, Amin AR and Clancy R: Nitric oxide and inflammatory mediators in the perpetuation of osteoarthritis. Curr Rheumatol Rep 3: 535-541, 2001.

2. Chung HY, Cesari M, Anton S, Marzetti E, Giovannini S, Seo AY, Carter C, Yu BP and Leeuwenburgh C: Molecular inflammation: underpinnings of aging and age-related diseases. Ageing Res Rev 8: 18-30, 2009.

3. Murakami A and Ohigashi H: Targeting NOX, INOS and COX-2 in inflammatory cells: chemoprevention using food phytochemicals. Int J Cancer 121: 2357-2363, 2007.

4. Mariotto S, Suzuki Y, Persichini T, Colasanti M, Suzuki H and Cantoni O: Cross-talk between NO and arachidonic acid in inflammation. Curr Med Chem 14: 1940-1944, 2007.

5. Phoa $\mathrm{N}$ and Epe B: Influence of nitric oxide on the generation and repair of oxidative DNA damage in mammalian cells. Carcinogenesis 23: 469-475, 2002

6. Ramsay RG, Ciznadija D, Vanevski M and Mantamadiotis T: Transcriptional regulation of cyclo-oxygenase expression: three pillars of control. Int J Immunopathol Pharmacol 16: S59-S67, 2003.

7. Honda S, Migita K, Hirai Y, Ueki Y, Yamasaki S, Urayama S, Kawabe Y, Fukuda T, Kawakami A, Kamachi M, Kita M, Ida H, Aoyagi $\mathrm{T}$ and Eguchi K: Induction of COX-2 expression by nitric oxide in rheumatoid synovial cells. Biochem Biophys Res Commun 268: 928-931, 2000.

8. Fairweather D and Cihakova D: Alternatively activated macrophages in infection and autoimmunity. J Autoimmun 33: 222-230, 2009.

9. Dinarello CA: A clinical perspective of IL-1 $\beta$ as the gatekeeper of inflammation. Eur J Immunol 41: 1203-1217, 2011.

10. Atreya I, Atreya R and Neurath MF: NF-kappaB in inflammatory bowel disease. J Intern Med 263, 591-596, 2008

11. Sebban H and Courtois G: NF-kappaB and inflammation in genetic disease. Biochem Pharmacol 72: 1153-1160, 2006.

12. Park GY and Christman JW: Nuclear factor kappa B is a promising therapeutic target in inflammatory lung disease. Curr Drug Targets 7: 661-668, 2006.
13. Oeckinghaus A and Ghosh S: The NF-kappaB family of transcription factors and its regulation. Cold Spring Harb Perspect Biol 1: a000034, 2009.

14. Kim SH, Smith CJ and Van Eldik LJ: Importance of MAPK pathways for microglial pro-inflammatory cytokine IL-1 beta production. Neurobiol Aging 25: 431-439, 2004.

15. Kaminska B, Gozdz A,Zawadzka M, Ellert-Miklaszewska A and Lipko M: MAPK signal transduction underlying brain inflammation and gliosis as therapeutic target. Anat Rec (Hoboken) 292: 1902-1913, 2009.

16. Wei J and Feng J: Signaling pathways associated with inflammatory bowel disease. Recent Pat Inflamm Allergy Drug Discov 4: 105-117, 2010.

17. Ramos S: Cancer chemoprevention and chemotherapy: dietary polyphenols and signalling pathways. Mol Nutr Food Res 52: 507-526, 2008.

18. Chen J, Chua KW, Chua CC, Yu H, Pei A, Chua BH, Hamdy RC, $\mathrm{Xu} \mathrm{X}$ and Liu CF: Antioxidant activity of 7,8-dihydroxyflavone provides neuroprotection against glutamate-induced toxicity. Neurosci Lett 499: 181-185, 2011.

19. Dixon RA and Steele CL: Flavonoids and isoflavonoids - a gold mine for metabolic engineering. Trends Plant Sci 4: 394-400, 1999.

20. Chen D, Chen MS, Cui QC, Yang H and Dou QP: Structureproteasome-inhibitory activity relationships of dietary flavonoids in human cancer cells. Front Biosci 12: 1935-1945, 2007.

21. Szejtli J and Szente L: Elimination of bitter, disgusting tastes of drugs and foods by cyclodextrins. Eur J Pharm Biopharm 61: $115-125,2005$

22. Curin Y and Andriantsitohaina R: Polyphenols as potential therapeutical agents against cardiovascular diseases. Pharmacol Rep 57: S97-S107, 2005 .

23. Pan MH and Ho CT: Chemopreventive effects of natural dietary compounds on cancer development. Chem Soc Rev 37: 2558-2274, 2008.

24. Prasad S, Phromnoi K, Yadav VR, Chaturvedi MM and Aggarwal BB: Targeting inflammatory pathways by flavonoids for prevention and treatment of cancer. Planta Med 76: 1044-1063, 2010.

25. Chahar MK, Sharma N, Dobhal MP and Joshi YC: Flavonoids: A versatile source of anticancer drugs. Pharmacogn Rev 5: 1-12, 2011.

26. Guo W, Kong E and Meydani M: Dietary polyphenols, inflammation, and cancer. Nutr Cancer 61: 807-810, 2009.

27. Jang SW, Liu X, Yepes M, Shepherd KR, Miller GW, Liu Y, Wilson WD, Xiao G, Blanchi B, Sun YE and Ye K: A selective TrkB agonist with potent neurotrophic activities by 7,8-dihydroxyflavone. Proc Natl Acad Sci USA 107: 2687-2692, 2010.

28. Andero R, Heldt SA, Ye K, Liu X, Armario A and Ressler KJ: Effect of 7,8-dihydroxyflavone, a small-molecule TrkB agonist, on emotional learning. Am J Psychiatry 168: 163-172, 2011.

29. Kozics K, Valovicova $Z$ and Slamenova D: Structure of flavonoids influences the degree inhibition of Benzo(a)pyrene-induced DNA damage and micronuclei in HepG2 cells. Neoplasma 58: 516-524, 2011.

30. Zhang R, Kang KA, Piao MJ, Ko DO, Wang ZH, Chang WY, You HJ, Lee IK, Kim BJ, Kang SS and Hyun JW: Preventive effect of 7,8-dihydroxyflavone against oxidative stress induced genotoxicity. Biol Pharm Bull 32: 166-171, 2009.

31. Divsalar A, Saboury AA, Ahadi L, Zemanatiyar E and Mansouri-Torshizi H: Investigation of effects of newly synthesized $\mathrm{Pt}(\mathrm{II})$ complex against human serum albumin and leukemia cell line of K562. BMB Rep 43: 766-771, 2010.

32. Woo A, Min B and Ryoo S: Piceatannol-3'-O-beta-D-glucopyranoside as an active component of rhubarb activates endothelial nitric oxide synthase through inhibition of arginase activity. Exp Mol Med 42: 524-532, 2010.

33. Lee SH, Kim DW, Back SS, Hwang HS, Park EY, Kang TC, Kwon OS, Park JH, Cho SW, Han KH, et al: Transduced Tat-Annexin protein suppresses inflammation-associated gene expression in lipopolysaccharide (LPS)-stimulated Raw 264.7 cells. BMB Rep 44: 484-489, 2011.

34. Choi JH, Park JG, Jeon HJ, Kim MS, Lee MR, Lee MN, Sonn S, Kim JH, Lee MH, Choi MS, et al: 5-(4-Hydroxy2,3,5-trimethylbenzylidene) thiazolidine-2,4-dione attenuates atherosclerosis possibly by reducing monocyte recruitment to the lesion. Exp Mol Med 43: 471-478, 2011.

35. Issac TT, Dokainish H and Lakkis NM: Role of inflammation in initiation and perpetuation of atrial fibrillation: a systematic review of the published data. J Am Coll Cardiol 50: 2021-2028, 2007. 
36. Strober W and Fuss IJ: Proinflammatory cytokines in the pathogenesis of inflammatory bowel diseases. Gastroenterology 140: 1756-1767, 2011.

37. Nam NH: Naturally occurring NF-kappaB inhibitors. Mini Rev Med Chem 6: 945-951, 2006.

38. Luqman S and Pezzuto JM: NFkappaB: a promising target for natural products in cancer chemoprevention. Phytother Res 24: 949-963, 2010

39. Shin EM, Zhou HY, Guo LY, Kim JA, Lee SH, Merfort I, Kang SS, Kim HS, Kim S and Kim YS: Anti-inflammatory effects of glycyrol isolated from Glycyrrhiza uralensis in LPS-stimulated RAW264.7 macrophages. Int Immunopharmacol 8: 1524-1532, 2008.
40. Pyo H, Jou I, Jung S, Hong S and Joe EH: Mitogen-activated protein kinases activated by lipopolysaccharide and beta-amyloid in cultured rat microglia. Neuroreport 9: 871-874, 1998.

41. Guha M and Mackman N: LPS induction of gene expression in human monocytes. Cell Signal 13: 85-94, 2001. 